\title{
Images, Satisfaction and Antecedents: Drivers of Student Loyalty? A Case Study of a Norwegian University College
}

\author{
Øyvind Helgesen \\ Aalesund University College, Institute of International Marketing (IIM), \\ Ålesund, Norway \\ Erik Nesset \\ Aalesund University College, Institute of International Marketing (IIM), \\ Ålesund, Norway
}

\begin{abstract}
Even if images and allied constructs, especial$1 y$ identity and reputation, have received considerable attention in recent years, research efforts have mainly focused on those allied constructs and not on their interplay with related constructs. This study examines two models to explore the relationships among service quality, facilities, student satisfaction, image of the university college, and image of the study program, with student loyalty as the ultimate dependent variable. The students perceive the image of the university college and the image of the study program as two distinct concepts. The study's preferred model only indirectly relates the image of the study program to student loyalty (via the image of the university college) while student satisfaction and the image of the university college are directly related to student loyalty. Student satisfaction has the highest degree of association with student loyalty, representing a total effect about three times the effect of the image of the university college. Service quality only loads on student satisfaction, while the variable representing facilities loads on student satisfaction, the image of the university college and the image of the study program. The predictor variables included can explain a considerable amount of the variance of student loyalty.
\end{abstract}

Corporate Reputation Review (2007) 10, 38-59. doi:10.1057/palgrave.crr.1550037

KEYWORDS: image of university college; image of study program; reputation; student satisfaction; student loyalty; structural equation modelling

\section{INTRODUCTION}

Images and allied constructs, especially identity and reputation, have received considerable attention in recent years (Fombrun, 1996; Dowling, 2001; Fombrun and van Riel, 1997, 2003). The constructs are defined and linked together in various ways (Chun, 2005; Brown et al., 2006). In this study, corporate image is referring to outside stakeholders' perceptions of an organization, corporate identity to internal stakeholders' perceptions, whereas corporate reputation includes views of both internal and external stakeholders (Chun, 2005). Thus corporate reputation is perceived as being an umbrella construct, referring to the cumulative impressions of internal and external stakeholders, especially the impressions of employees and customers. Image building is perceived as being strategically important for many organizations, especially for professional service providers (Zabala et al., 2005).
Corporate Reputation Review,
Vol. 10, No. 1, pp. 38-59

(c) 2007 Palgrave Macmillan Ltd, 1363-3589 \$30.00 
Images can be formed for many different entities, such as products, brands and organizations (Lemmink et al., 2003), and even countries (Passow et al., 2005).

Helm (2005: 106) believes that the understanding of the reputation construct has been dominated by research focused on the construct itself; inclusion of reputation in structural equation modelling in order to examine its interplay with other constructs has remained scarce'. Chun (2005: 104) states that 'links between customer satisfaction and the image of an organization have been under-researched'. The main purpose of this paper is to study the relationships between various images and related constructs, with the goal of gaining insight into the interplay between these concepts. The context is higher education, specifically a Norwegian university college. The study focuses on the following variables: service quality, facilities (of the university college), student satisfaction, image of the university college, image of the study program and student loyalty. The latter is used as the ultimate dependent variable for the model. The two first variables are factors (exogenous variables), while the other four are the main concepts (endogenous variables) in the model. The study addresses these main research questions: (1) Are students' perceived image of the university college and their perceived image of their specific study program different concepts? (2) Are student satisfaction, image of the university college and image of the study program all drivers of student loyalty, and if so, which one has the highest degree of association with student loyalty?

Student loyalty is becoming increasingly important for institutions offering higher education. The reasons are manifold as discussed below. It should be underscored, however, that students are not the only constituencies that may be categorized as customers of higher educational institutions. Employers, families and the society may also be looked upon as customers (Marzo-Navarro et al., 2005a). Thus stakeholders other than students could also be included in studies regarding loyalty of educational institutions. In this paper, the focus is on students as customers.

Researchers have perceived and defined the concept of loyalty in a number of different ways. Loyalty is assumed to be positively related to the ability of an institution to both attract new students and retain existing ones (see, eg, Dick and Basu, 1994; Oliver, 1997; Henning-Thurau et al., 2001). Increased global competition among institutions offering higher education means that retaining matriculated students is just as important as attracting and enrolling them (Kotler and Fox, 1995; Elliott and Healy, 2001).

In recent years, governments have changed the way that they finance institutions of higher education, with financial support more strongly linked to the results that educational institutions produce (Arnaboldi and Azzone, 2005; DeShields et al., 2005). To a great extent, the current financing system is based on the production of student credits and professional degrees. Thus the defection of one student can mean that a university or another degree-granting institution may see an associated drop in future funding. In Norway, the performance-based funding on average represents about $\mathcal{E} 3,000$ on a yearly basis for each student in public-owned institutions. Thus students constitute an important source of financing not only for private higher educational institutions, but also for public ones.

Student loyalty is influenced by increased student mobility, which gives the process of attracting students a new dimension. Regarding student mobility, the Bologna Process is becoming increasingly influential for higher educational institutions of the Bologna Process Area. The Bologna Process was established in June 1999, when 29 European higher education ministers met in Bologna ${ }^{1}$ 
to lay the groundwork to establish a European Higher Education Area by 2010, and to promote the European system of higher education worldwide. Follow-up summits ${ }^{2}$ have been held every second year. The Bologna Process currently has 45 member countries, and focuses on ten topics such as the adoption of a system of easily readable and comparable degrees, establishment of a common system of credits (ECTS), ${ }^{3}$ and promotion of mobility. One of the main objectives has been to enhance and facilitate student and teacher mobility by removing obstacles and improving the international recognition of degrees and academic qualifications. Thus, students are encouraged to spend at least one semester abroad. Various means or programs ${ }^{4}$ have been introduced to promote the various aims of the Bologna Process such as Erasmus, ${ }^{5}$ Sokrates and Leonardo da Vinci. Regarding students the Norwegian financial system implies that an educational institution receiving students from abroad is credited for all the ECTS obtained by the foreign students as well as an extra remuneration (about $£, 500$ for each semester). This extra remuneration is also received for Norwegian students studying abroad. Some countries in the Bologna Process Area have found it a great challenge to attract students from abroad in order to compensate for their 'own' students leaving to pursue their studies abroad. These institutions also would like their outgoing students to return to the home institution to complete their degrees.

Norwegian higher education reform legislation from 2003 (Quality Reform in Norwegian Higher Education) made student loyalty an increasingly important issue for Norwegian institutions. The reforms were designed to create a new degree structure in keeping with the Bologna Process and its new flexible, modular study programs. Lawmakers also created a Quality Assurance Agency (NOKUT), ${ }^{6}$ revised the system of financial support for students, and promoted new approaches to teaching and assessment at the higher educational level. The reforms also resulted in the standardization of many study programs. Thus students can leave one institution and continue their studies at another educational institution without major difficulties. Students in Norway also have a legal right to switch to other educational institutions as long as they meet all of the new institution's requirements, particularly regarding the study program. Either the 'first' educational institution has to agree to approve the student's study program and take responsibility for the student's degree, or the 'second' educational institution has to approve courses that have been completed earlier, and thus accept responsibility for the student's degree. These combined factors have torn down barriers to student mobility both in Norway and in the 45 Bologna Process participant countries.

Once students have completed their degrees, they can still continue to maintain a relationship with their educational institution, by participating in conferences and other arrangements, or by acting as the institute's advocates. A growing number of former students are also returning to higher educational institutions to continue education courses (Marzo-Navarro et al., 2005b). Additionally, student loyalty is positively related to teaching quality as reflected in students' active participation and committed behavior (Rodie and Kleine, 2000). Consequently, institutions of higher education should find insight regarding student loyalty and the drivers or variables influencing student loyalty of great strategic importance (Marzo-Navarro et al., 2005b; Schertzer and Schertzer, 2004).

This paper is organized as follows. The next section discusses conceptual models and hypotheses. Then, the context, data and research methodology are briefly discussed, followed by a presentation of the results. The paper then presents a discussion of findings and their implications for managers. The 
paper ends with a presentation of limitations, suggestions for further research and a conclusion.

\section{CONCEPTUAL MODELS AND HYPOTHESES}

The main concepts underlying this study are drawn from various theoretical and conceptual frameworks and models. The concepts form the cornerstone of various National Customer Barometers (Fornell, 1992; Fornell et al., 1996; Chan et al., 2003). Most often, measures of these concepts are included in goal hierarchies of balanced scorecard approaches and/or of business models (Kaplan and Norton, 1996, 2001, 2004). For years they have been included in quality models and related quality awards for business excellence (Heaphy and Gruska, 1995; Oakland, 1995). Even more important, they form the central concepts in most of the various service quality approaches (Seth et al., 2004). Relationships between images and loyalty, however, are not receiving the same research attention as relationships between satisfaction and loyalty (including antecedents and consequences).
Figure 1 presents the preferred theoretical structural model of the study and the hypothesized relationships. Customer loyalty is supposed to have a positive impact on the performance of business units both at an aggregate level and at the individual customer level (Anderson et al., 1994; Yeung and Ennew, 2000; Helgesen, 2006). Thus, a business unit with focus on the concepts illustrated in Figure 1 should implicitly have as its main objective long-term profitability, which implies that the prevailing philosophy of the business unit is based on the marketing concept (eg Drucker, 1954; Felton, 1959; Grönroos, 1989).

The variables Student Satisfaction, Image of University College and Image of Study Program are assumed to be drivers of Student Loyalty, as will be subsequently discussed. The model also includes two antecedents. Arguments can, however, be put forward for turning the arrow from Image of Study Program to Image of University College the other way around, that is, assuming the opposite causal order. In fact, the common notion in the general literature on image is to allow corporate (brand) image to have a spillover effect on

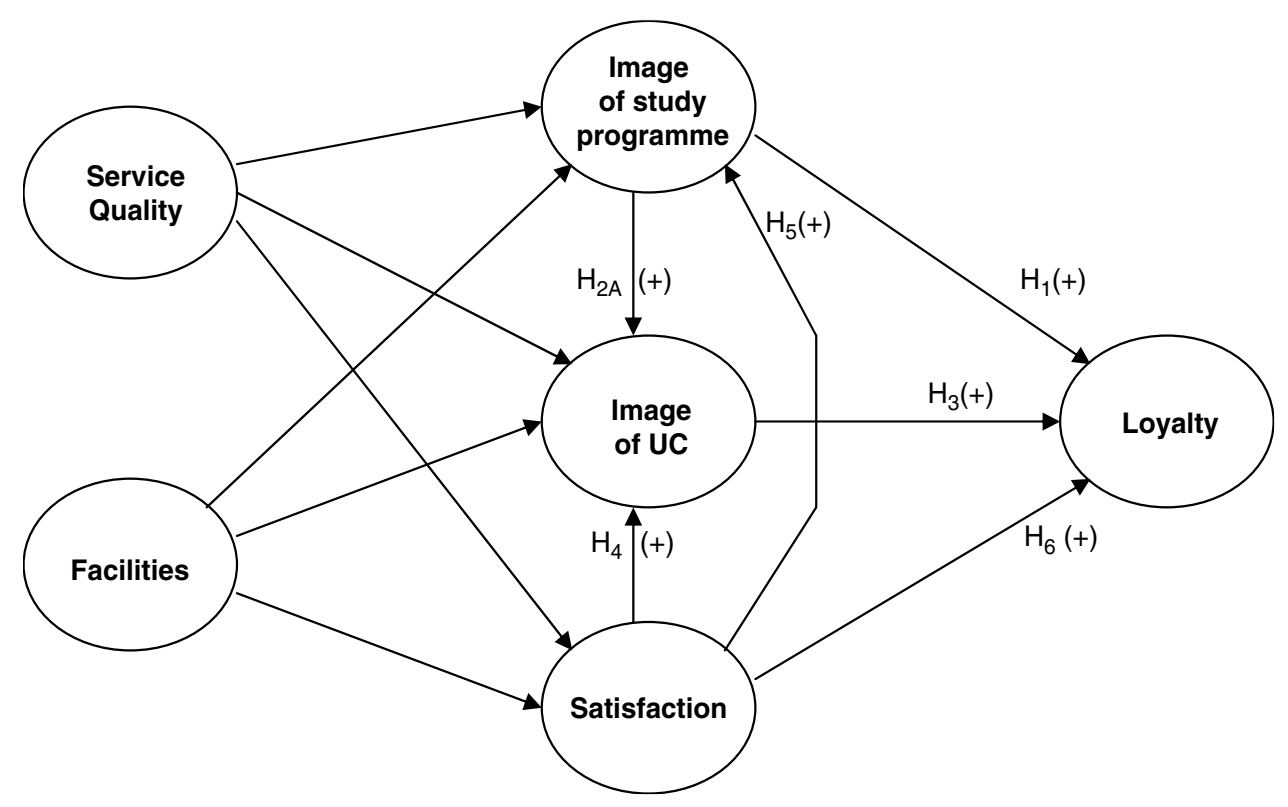

Figure 1: The preferred theoretical structural model 
their product brand image. Considering the particular context of the study, this paper will, however, argue for the chosen causal order, and the next sections elaborate on this matter. An alternative model supposing an opposite causal order between Image of University College and Image of Study Program is also, however, analyzed and discussed.

\section{Student Loyalty}

Oliver (1997: 392) has defined customer loyalty as 'a deeply held commitment to rebuy or repatrionize a preferred product or service consistently in the future, despite situational influences and marketing efforts having the potential to cause switching behavior', while Lam et al. (2004: 294) see it as 'a buyer's overall attachment or deep commitment to a product, service, brand, or organization'. These are but two of numerous definitions of this concept (eg Reynolds et al., 1974-75: Reichheld, 1996; Mägi, 1999). Oliver $(1997,1999)$ relates customer loyalty to a four-stage model: cognitive loyalty, affective loyalty, conative loyalty and action loyalty. Dick and Basu (1994) perceive loyalty as being based on two interrelated components: relative attitude and repeat patronage, where the former is related to cognitive, affective and conative antecedents. Thus, customer loyalty can be looked upon as a concept containing a tripartite attitudinal component (cognitive, affective and conative) and a closely related behavioral component (repeat patronage-customer retention) (eg Johnson and Gustafsson, 2000; Lam et al., 2004).

Paralleling the related concept of customer loyalty, student loyalty also contains an attitudinal component and a behavioral component (Henning-Thurau et al., 2001; Marzo-Navarro et al., 2005a). The attitudinal component can be defined as tripartite, consisting of cognitive, affective and conative elements. The behavioral component can be perceived as being related to decisions that students make regarding their mobility options. Student loyalty, however, is not restricted to the period during which students are formally registered as students. The loyalty of former students can also be highly important for an educational institution. Therefore, student loyalty can be related both to the period when a student is formally enrolled as well the period after the student has completed his or her formal education at the institution. An institution offering higher education naturally has as one of its primary goals to have students who are committed to the institution despite situational influences (action loyalty). This paper bases measurements of student loyalty on the attitudinal component of the concept, that is, the students' behavioral intentions (eg Zeithaml et al., 1996; Jones et al., 2000; Henning-Thurau et al., 2001).

\section{Images and Allied Constructs}

Images and allied constructs (identity, reputation, etc) are defined and linked together in various ways (Chun, 2005; Brown et al., 2006). In this study, corporate images are referring to external stakeholders' perceptions of an organization, corporate identity to internal stakeholders' perceptions, whereas corporate reputation includes views of both internal and external stakeholders (Chun, 2005). Thus corporate reputation is interpreted as the overall perception of a company, what it stands for, what it is associated with and what individuals may expect when buying the products or using the company's services (Fombrun and Shanley, 1990; MacMillan et al., 2005), and defined as 'the overall estimation in which a company is held by its constituents' (Fombrun, 1996: 37). Corporate reputation is formed in all instances when the company is in interaction with its stakeholders (Theus, 1993; Schuler, 2004) and reflects the history of its past actions (Yoon et al., 1993).

Corporate identity (desired identity) may be perceived as 'the firm's visual statement to the world of who and what the company 
is - of how the company views itself' (Selame and Selame, 1988), or as 'the tangible manifestation of the personality of a company' (Olins, 1999). Corporate images are formed by various groups of external stakeholders and can be defined as their 'summary of the impressions or perceptions of a company' (Chun, 2005: 95).

Image building is looked upon as being essential for attracting and retaining students, that is, important drivers of student loyalty (Sevier, 1994; Bush et al., 1998; Standifird, 2005). Various constituencies may form images about a variety of entities such as products, brands, organizations or institutions (Fombrun, 1996; Lemmink et al., 2003), and even countries (Passow et al., 2005). Consequently, students may form images of both their university college and their specific study program. Loyalty is supposed to be positively affected by favorably perceived images (Selnes, 1993; Rindovea and Fombrun, 1999; Johnson et al., 2001; MacMillan et al., 2005). Thus, both the image of a university college and the image of a study program of a university college are assumed to have positive effects on student loyalty. An organization has several images and the various images can be assumed to be positively related (Dowling, 1988; Lemmink et al., 2003). The common notion is that corporate brand image has a spillover effect on their product brand image (see eg Kinnear et al., 1995; Kotler et al., 2002), which in this study implies a spillover effect from the image of the university college to the image of the study programs. The linkages between the various concepts, however, are not straightforward (Dowling, 1986; Markwick and Fill, 1997; Lemmink et al., 2003). Additionally, contextual aspects may be of importance regarding these linkages. Thus this study suggests that the image of the university college is influenced by the various study programs, due to the fact that the university college is new, the product of a merger of three former educational institutions. These arguments suggest the following hypotheses:

$\mathbf{H}_{\mathbf{1}}$ : Student perception of the image of the study program has a positive impact on student loyalty.

$\mathbf{H}_{2 \mathbf{A}}$ : Student perception of the image of the study program has a positive impact on student perception of the image of the university college.

$\mathbf{H}_{3}$ : Student perception of the image of the university college has a positive impact on student loyalty.

The proposed hypotheses are based on the preferred theoretical structural model of the study. An alternative model assuming a spillover effect from the image of the university college to the image of the study programs is also analyzed and discussed below. In employing this alternative model, all other hypotheses can remain unchanged, so that only one alternative hypothesis is offered:

$\mathbf{H}_{2 \mathbf{B}}$ : Student perception of the image of the university college has a positive impact on student perception of the image of the study program.

\section{Student Satisfaction}

Customer satisfaction may be perceived as a summary psychological state or a subjective summary judgment based on the customer's experiences compared with expectations. The concept has been defined in various ways, for example, as 'an overall feeling, or attitude, a person has about a product after it has been purchased' (Solomon, 1994: 346), or as a 'summary, affective and variable intensity response centered on specific aspects of acquisition and/or consumption, and which takes place at the precise moment when the individual evaluates the object' 
(Giese and Cote, 2000: 3). Student satisfaction is perceived as a parallel concept that can be defined in various ways (Browne et al., 1998; Elliot and Healy, 2001; Elliott and Shin, 2002; DeShields et al., 2005; Marzo-Navarro et al., 2005a), for example as 'a short-term attitude resulting from an evaluation of a student's educational experience' (Elliott and Healy, 2001: 2), or as 'a student's subjective evaluation of the various outcomes and experiences with education and campus life' (Elliott and Shin, 2002: 198).

Customer loyalty is often perceived as the main consequence of customer satisfaction (eg Fornell, 1992; Fornell et al., 1996; Chan et al., 2003). Researchers have also found student satisfaction to be positively related to student loyalty (eg Athiyaman, 1997; Marzo-Navarro et al., 2005b; Schertzer and Schertzer, 2004).

Customer satisfaction is not only positively related to customer loyalty, but also to corporate image, corporate reputation and brand reputation (Selnes, 1993; Anderson et al., 1994; Johnson and Gustafsson, 2000; Johnson et al., 2001; Oliver, 1980). Johnson et al. (2001) have studied various national customer satisfaction index models and have offered advice regarding these models, for example, that the "corporate image should be modeled as an outcome rather than a driver of satisfaction. The effect of satisfaction on corporate image reflects both the degree to which customers' purchase and consumption experiences enhance a product's or service provider's corporate image and the consistency of customers' experiences over time' (Johnson et al., 2001: 231-232). Students have experiences related to both their study program and the university college. Thus, student satisfaction is assumed to have a positive impact both on the students' image of the university college and on the students' image of the specific study program. These arguments suggest the following hypotheses:
$\mathbf{H}_{\mathbf{4}}$ : Student satisfaction has a positive impact on student perception of the image of the university college.

$\mathbf{H}_{5}$ : Student satisfaction has a positive impact on student perception of the image of the study program.

$\mathbf{H}_{\mathbf{6}}$ : Student satisfaction has a positive impact on student loyalty.

\section{Antecedents of Satisfaction and Images}

Researchers have introduced and studied a number of models and variables (antecedents or drivers) to explain variations in satisfaction, images and loyalty (eg Johnson et al., 2001; Seth et al., 2004; Williams et al., 2005). Evaluation standards such as SERVQUAL (Parasuraman et al., 1988, 1994) and SERVPERF (Cronin and Taylor, 1992) have been developed to function independent of any particular service context. While these scales might help identify a set of drivers or antecedents that have some general relevance, researchers have also been advised to consider additional dimensions that are derived from industry-specific contexts (Athiyaman, 1997; Athanassopoulos, 2000; Abdullah, 2005). The literature on higher education offers numerous context-specific dimensions or items to be included in questionnaires (Aldridge and Rowley, 1998; Elliott and Shin, 2002; Marzo-Navarro et al., 2005b). A number of variables may influence student satisfaction or the students' perceptions of the image of a university college and the image of a study program. The main purpose is to select antecedents that are believed to be important and that can precisely indicate what should be done in order to obtain increased value for money (Zeithaml, 2000; McNair et al., 2001; Guilding and McManus, 2002).

Students' perceptions of an educational institution's facilities and the quality of service provided are among the antecedents most 
often used. Thus this study includes items measuring those two dimensions. These two variables are considered not concepts but factors (exogenous variables).

\section{CONTEXT, DATA AND RESEARCH METHODOLOGY}

Aalesund University College (AAUC) was founded in 1994 as a result of a reorganization of higher education in Norway. Three former colleges in Aalesund, the College of Marine Studies, the College of Engineering and Aalesund College of Nursing were merged into one institution. The college has an enrolment of approximately 1,900 students (1,300 full-time) with 140 academic and administrative staff members. AAUC offers the following undergraduate study programs: Engineering studies (Civil Engineering, Mechanical Engineering and Naval Product Development and Design, Computer Engineering, Automation, Geographical Information Systems, Nautical Studies), Business/Marketing studies (Business Administration, Export Marketing, International Logistics, Innovation Management and Entrepreneurship), Health Care studies (Nursing, Biomedical Laboratory Science) and Fisheries and Aquaculture studies (Marine Biology and Seafood Processing). The diversity of study programs reflects AAUC's genesis as a merger of three quite different colleges. Three of the study areas, that is, business/marketing studies, nautical/marine/ maritime engineering studies, and fisheries and aquaculture studies, have been developed in close cooperation with the regional industrial environment (the marine and maritime industrial cluster).

Students in the study sample are recruited from different years in all of AAUC's bachelor study programs. The total sample consists of 454 respondents (204 male and 250 female students) representing about 35 per cent of the full-time students. The mean age of the respondents is 24.8 years. A comparison of the sample with the population (AAUC students), suggests that the sample is not non-representative of the population.

\section{Main Concept Measurement}

The main concepts in this study are student loyalty, image of the university college, image of the study program and student satisfaction, as shown in Figure 1. Researchers have reached no consensus concerning the measurements of these concepts (eg Fornell, 1992; Oliver, 1997; Davies et al., 2004; Lam et al., 2004; Chun, 2005). Many researchers, however, have offered valuable advice, which has been taken into account in developing the measurement model.

Twenty-five items (indicators) are used to measure study concepts and factors, 13 of which measure the four main concepts and 12 of which measure the two factors (antecedents). All indicators are measured on a seven-point Likert scale where ' 1 ' indicates the least favorable response alternative (very unsatisfied) and ' 7 ' the most favorable response alternative (very satisfied). Appendix A presents the statistical metrics of the 25 items and Appendix B the correlation matrix. All correlation coefficients higher than approximately 0.16 are significant at the 0.001 level, those higher than 0.12 at the 0.01 level, and those higher than 0.10 at the 0.05 level.

Accordingly, Student Loyalty is measured by asking about behavioral intentions (three items): the probability of recommending the university college to friends/acquaintances, the probability of attending the same university college if starting anew, and the probability of attending new courses/further education at the university college, cf. Appendices $\mathrm{A}$ and $\mathrm{B}$.

Based on the preceding discussion and definitions (eg Fombrun, 1996; Chun, 2005), the Image of University College is measured with three items: the students' perception of the university college among her/his circle of acquaintances, the students' perception of the university college among the general 
public and the students' perception of the university college among employers. Image of Study Program is measured in an analogous way. This assumes that the students' perceptions of the two kinds of images are developed by their perceptions of the external prestige of the AAUC in general and the specific study program in particular. The questioning approach selected is commonly called a third-party technique or projective questioning (see eg Wilson, 2003). Answers to these types of questions usually reflect the opinions of the respondents, here regarding various constituencies, thus increasing the reliability and validity of the measurements.

Ryan et al. (1995) assert that satisfaction may be measured by asking questions related to three aspects: summary judgement, comparison with expectations and comparison with an ideal situation. This is also the approach selected for this study. In addition an initial question concerning the students' spontaneous judgments of their satisfaction with the university college is included.

\section{Measures of the Antecedents}

The survey originally included 21 antecedents (items). Because the main purpose of this paper is to analyze the relationships between two images and related constructs (satisfaction and loyalty), an exploratory factor analysis of the antecedents (principle components with varimax rotation) has been elaborated prior to a confirmative analysis. During this data reduction process, nine items were excluded (due to low factor loadings and communalities). Finally, 12 items related to two factors were extracted. Appendix A shows the statistical metrics of the 12 indicators, while Table 1 shows the factor loadings according to the confirmatory analysis. The first factor is called Facilities and the second Service Quality.

\section{Data analysis Approach}

The data analysis approach follows the twostep confirmative modelling strategy pro- posed by Hair et al. (2006). First a statistical congruent (and congeneric) measurement model of the latent variables is developed. In step two, these variables are used in a structural equation analysis setting, where the six hypotheses are tested (cf. Figure 1). The analysis is based on a covariance structure approach by using LISREL 8.50 (Jöreskog and Sörbom, 1996; Jöreskog et al., 2001).

\section{RESULTS}

\section{The Measurement Model}

Appendices A and B present statistical metrics of the observed items and the correlation coefficients between them, respectively. It should be noted that Student Loyalty was initially measured with three items. In the process of validating the measurement model however, one item was excluded $\left(\mathrm{Y}_{13}\right.$ : Probability of attending new courses/further education at the university).

Table 1 presents the standardized coefficients (loadings) of the six latent variables and two measures of convergent validity for each latent variable. All the four main concepts (Student Satisfaction, Image of University College, Image of Study Program and Student Loyalty) have statistically significant loadings (ranging from 0.71 to 0.93). Both Cronbach's alpha (CA) and construct reliability (CR) exceed the minimum recommended level (0.70) for all main constructs. Another measure of convergent validity is the variance extracted (VE), reported along the diagonal of Table 2. All the main concepts have a VE well above the minimum recommended value of 0.50 .

The picture is mixed regarding the two factors reflected by the 12 antecedents. The Facilities factor consists of seven statistically significant loadings. Both CA (0.78) and CR (0.78) are acceptable, but VE (0.34) is below the recommended level. In the Service Quality factor all loadings (5) are significant. CA (0.72) and CR (0.73) are acceptable, whereas 
Table 1: Measurement Model Results: Completely Standardized Coefficients and Convergent Validity Measures

\begin{tabular}{|c|c|c|c|c|}
\hline acilities & $\begin{array}{l}\text { Service } \\
\text { quality }\end{array}$ & Satisfaction & $\begin{array}{l}\text { Image } \\
U C\end{array}$ & $\begin{array}{l}\text { Image } \\
\text { study }\end{array}$ \\
\hline
\end{tabular}

Satisfaction with the reading room

Satisfaction with the library

Satisfaction with the locations of lectures

Satisfaction with the group rooms

Satisfaction with the cleaning

Satisfaction with the indoor temperature

Satisfaction with the canteen

Satisfaction with the pedagogical quality of lectures

Satisfaction with the feedback from lecturers

Satisfaction with the professional quality of lectures

Satisfaction with the students' mid-term evaluations

regarding their study

Satisfaction with the quality of study materials

Satisfaction with the university college (spontaneous judgment)

Satisfaction with the university college in general

Satisfaction with the university college compared with expectations

Satisfaction with the university college compared with an ideal one

Perception of the university college among your circle of

acquaintances

Perception of the university college among the general public

Perception of the university college among employers

Perception of the study among your circle of acquaintances

Perception of the study among the general public

Perception of the study among employers

Probability of recommending the university college to friends/

acquaintances
0.69
0.69
0.59
0.56
0.55
0.49
0.50

0.75
0.60
0.69
0.48
0.41

0.87
0.90
0.81
0.79

0.82

0.86

0.71

0.85

0.86

0.71

0.93

0.75

Probability of attending new courses/further education at the university

Convergent Validity:

Cronbach's alpha (CA)

0.78

0.72

0.91

0.83

0.85

$0.84 \quad 0.85$

0.82

$\begin{array}{llllll}0.78 & 0.73 & 0.91 & 0.84 & 0.85 & 0.83\end{array}$

${ }^{\mathrm{a}}$ Construct reliability: $\left(\sum_{\mathrm{i}}^{\mathrm{n}} \lambda i\right)^{2} /\left(\sum_{\mathrm{i}}^{\mathrm{n}} \lambda_{\mathrm{i}}\right)^{2}+\left(\sum_{\mathrm{i}}^{\mathrm{n}} \delta_{\mathrm{i}}\right)$, where $\lambda$ is standardized loading, $n$ is number of loadings and $\delta$ is the error variance

VE (0.36) is below the recommended level. The main concern is, however, connected to the hypothesized relationships between the four main concepts. All of these concepts are measured with items sharing a large proportion of variance in common.

Discriminant validity is examined by comparing the VE for each of the constructs with the square of the correlation coefficients between the construct considered and each of the other constructs of the model. In order to have a construct that is truly distinct from another construct, their respective VEs should be larger than the square of their correlation coefficient. Table 2 contains the information necessary to explore this. 
Table 2: Measurement Model Results: VEa and Squared Construct Correlations

\begin{tabular}{|c|c|c|c|c|c|c|}
\hline & Facilities & Service quality & Satisfaction & Image UC & Image study & Loyalty \\
\hline Facilities & 0.34 & & & & & \\
\hline Quality & 0.04 & 0.36 & & & & \\
\hline Satisfaction & 0.28 & 0.35 & 0.71 & & & \\
\hline Image UC & 0.24 & 0.22 & 0.49 & 0.64 & & \\
\hline Image study & 0.12 & 0.12 & 0.25 & 0.38 & 0.66 & \\
\hline Loyalty & 0.21 & 0.28 & 0.76 & 0.58 & 0.29 & 0.71 \\
\hline
\end{tabular}

${ }^{a}$ Variance extracted (diagonal): $\left(\sum_{\mathrm{i}}^{\mathrm{n}} \lambda_{\mathrm{i}}{ }^{2}\right) / n$, where $\lambda$ is standardized loading and $n$ is number of loadings

Discriminant validity is plagued by only one problem, which concerns the relationship between Student Loyalty and Student Satisfaction. Measuring Student Loyalty with the three original items instead of the two reported does not improve the discriminant validity test level. On the contrary, it is even worsened. The CA-, CR- and VE-values (convergent validity) of the variable are also smaller when using three items instead of two. A less restrictive test of discriminant validity fixes the correlation value between the two concepts to 1.0, and compares the $\chi^{2}$ of the restricted (total) measurement model with the $\chi^{2}$ of the unrestricted (total) measurement model. If $\Delta \chi^{2}$ is positive and significant (ie the restricted model exhibits significantly poorer overall fit), the two concepts can be claimed to be distinct, which is what is found $\left(\Delta \chi^{2}\right.$ is 17.63 , with $\left.d f=1\right)$. Another indication of discriminant validity of the various concepts of the model is the fact that the overall fit of the measurement model is quite satisfying taken into account that there are no cross-loadings and no covariances between or within construct error variances (ie a congeneric measurement model). Table 3 shows two absolute goodness-of-fit measures ( $\chi^{2}$ and root mean square error of approx. (RMSEA)), one incremental goodness-of-fit measure (comparative fit index (CFI)) and one badness-of-fit measure (stand. root mean square residual (SRMR)). The RMSEA has a value of 0.063 , CFI has a value of 0.92 and SRMR has a value of
0.049. All indices are satisfactory according to common guidelines offered in the literature (Byrne, 1998; Hair et al., 2006).

Inspection of the squared correlations between the measured variables (Table 2) indicates that the estimated measurement model makes sense (ie assuring nomological validity). The correlations are all in accordance with the proposed hypotheses and the preferred theoretical structural model illustrated in Figure 1.

\section{The Preferred Estimated Structural Model}

As shown in Table 4 the overall fit of the preferred estimated structural model is good $(\mathrm{RMSEA}=0.063, \quad \mathrm{CFI}=0.92, \quad \mathrm{SRMR}=$ 0.050). In the estimated alternative structural model, the path between the two types of images goes in the opposite direction, that is, from Image of University College to Image of Study Program (cf. Hypothesis 2B). As both models have the same number of parameters to be estimated, there is no difference in model fit. Table 5 shows the standardized coefficients of the hypothesized paths and the standardized coefficients of the paths from the two factors of antecedents to the main constructs for both model versions. The main difference between them is the significance of the path from Student Satisfaction to Image of Study Program. This path is significant in the preferred model but insignificant in the alternative model. Both models, however, assign a positive and significant 
Table 3: Measurement Model Results: Summary Statistics of Model Fit

\begin{tabular}{lc}
\hline$\chi^{2}$ (Minimum fit chi-square) & 643.03 \\
$\chi^{2} / d f$ & 2.71 \\
RMSEA $^{\text {a }}$ (root mean square & 0.063 \\
error of approx.) & \\
CFI $^{\text {b (comparative fit index) }}$ & 0.92 \\
SRMR $^{c}$ (stand. root mean & 0.049 \\
square residual) & \\
\hline
\end{tabular}

${ }^{\mathrm{a}} \mathrm{RMSEA}$ values below 0.08 indicate adequate fit

${ }^{\mathrm{b}} \mathrm{CFI}$ values close to 1 indicate a good fit

'SRMR values below 0.07 indicate adequate fit

path from Student Satisfaction to Image of University College. An important implication of the arguments put forward in the discussion of the theoretical framework of this study is that Student Satisfaction should positively influence both types of images, that is, both Image of University College and Image of Study Program. As Student Satisfaction is not significantly related to Image of Study Program in the alternative model, the other model version is preferred. In other contexts, however, the proposed hypotheses of the alternative model may be supported. This is further discussed below.

In the preferred model version, all the hypotheses except Hypothesis 1 (Student perception of the image of the study program has a positive impact on student loyalty) are supported, with standardized coefficients significant at the 0.01 level. The paths from Service Quality to Image of University College and Service Quality to Image of Study Program are insignificant, while the rest of the paths from the factors of antecedents to the main concepts are significant.

Figure 2 shows the results from the preferred estimated structural model, where all the insignificant paths are excluded. The direct effect from Student Satisfaction to Student Loyalty is 0.66 . There are in addition two indirect (mediated) effects via Image of University College and Image of Study Program (0.11 and 0.03 , respectively), giving a total
Table 4: Structural Model Results: Summary Statistics of Model Fit

\begin{tabular}{lc}
\hline$\chi^{2}$ (Minimum fit chi-square) & 645.55 \\
$\chi^{2} / d f$ & 2.69 \\
RMSEA $^{\text {a }}$ (root mean square & 0.063 \\
error of approx.) & \\
CFI $^{\text {b (comparative fit index) }}$ & 0.92 \\
SRMR $^{c}$ (stand. root mean & 0.050 \\
square residual) &
\end{tabular}

${ }^{a}$ RMSEA values below 0.08 indicate adequate fit

${ }^{\mathrm{b}} \mathrm{CFI}$ values close to 1 indicate a good fit

'SRMR values below 0.07 indicate adequate fit

effect from Student Satisfaction to Student Loyalty of 0.80. Image of Study Program has an indirect effect on Student Loyalty via Image of University College of 0.09, while Image of University College has a direct effect on Student Loyalty of 0.27. Changes in Image of University College and Student Satisfaction explains 80 per cent of the variance in Student Loyalty in the structural equation of Student Loyalty and 44 per cent of the variance in Student Loyalty in the reduced form equation of Student Loyalty.

\section{DISCUSSION AND MANAGERIAL IMPLICATIONS}

The main research questions addressed in this study are as follows: (1) Are the students' perceived image of the university college and their perceived image of their specific study program different concepts? (2) Are student satisfaction, image of the university college and image of the study program all drivers of student loyalty, and if so, which one has the highest degree of association with student loyalty? The results regarding the relationships between variables are summarized in Figure 2. (Insignificant paths are excluded.)

The findings indicate that students perceive the image of the university college and the image of the study program as two distinct concepts. Each of the two concepts is measured with three items. CA and CR exceed the minimum recommended level of 
Table 5: Structural Model Results: Standardized Coefficients (t-values in Parentheses)

\begin{tabular}{|c|c|c|c|c|}
\hline & & & Preferred model & Alternative model \\
\hline Path & Hypothesis & $\begin{array}{l}\text { LISREL } \\
\text { notation }\end{array}$ & Stand.coeff. (t-value) & Stand. coeff. (t-value) \\
\hline Image UC $\rightarrow$ Loyalty & $\mathbf{H}_{3}$ & $\mathrm{BE}(1,2)$ & $0.27\left(4.88^{\star \star}\right)$ & $0.27(4.88 \star \star)$ \\
\hline Image study $\rightarrow$ Loyalty & $\mathbf{H}_{1}$ & $\mathrm{BE}(1,4)$ & $0.04(0.97)$ & $0.04(0.97)$ \\
\hline Satisfaction $\rightarrow$ Loyalty & $\mathbf{H}_{6}$ & $\mathrm{BE}(1,3)$ & $0.66(13.42 \star \star)$ & $0.66(13.42 \star \star)$ \\
\hline Satisfaction $\rightarrow$ Image UC & $\mathbf{H}_{4}$ & $\mathrm{BE}(2,3)$ & $0.41(6.00 \star \star)$ & $0.53(7.47 \star \star)$ \\
\hline Image study $\rightarrow$ Image UC & $\mathbf{H}_{2 \mathrm{~A}}$ & $\mathrm{BE}(2,4)$ & $0.34\left(6.75^{\star \star}\right)$ & \\
\hline Image UC $\rightarrow$ Image Study & $\mathbf{H}_{2 \mathrm{~B}}$ & $\mathrm{BE}(4,2)$ & & $0.51\left(6.68^{\star \star}\right)$ \\
\hline Satisfaction $\rightarrow$ Image study & $\mathbf{H}_{5}$ & $\mathrm{BE}(4,3)$ & $0.37(4.61 \star \star)$ & $0.09(1.12)$ \\
\hline Service quality $\rightarrow$ Image UC & & $\mathrm{GA}(2,1)$ & $0.08(1.45)$ & $0.12(1.97)$ \\
\hline Service quality $\rightarrow$ Image study & & $\mathrm{GA}(4,1)$ & $0.11(1.55)$ & $0.05(0.71)$ \\
\hline Service quality $\rightarrow$ Satisfaction & & $\mathrm{GA}(3,1)$ & $0.51\left(10.55^{\star \star}\right)$ & $0.51\left(10.55^{\star \star}\right)$ \\
\hline Facility $\rightarrow$ Image UC & & $\mathrm{GA}(2,2)$ & $0.13\left(2.44^{\star}\right)$ & $0.18\left(3.15^{\star \star}\right)$ \\
\hline Facility $\rightarrow$ Image study & & $\mathrm{GA}(4,2)$ & $0.14\left(2.18^{\star}\right)$ & $0.05(0.80)$ \\
\hline Facility $\rightarrow$ Satisfaction & & $\mathrm{GA}(3,2)$ & $0.43(9.12 \star \star)$ & $0.43\left(9.12^{\star \star}\right)$ \\
\hline Service quality $\leftrightarrow$ Facility & & PHI $(1,2)$ & $0.19\left(3.32^{\star \star}\right)$ & $0.19(3.32 \star \star)$ \\
\hline
\end{tabular}

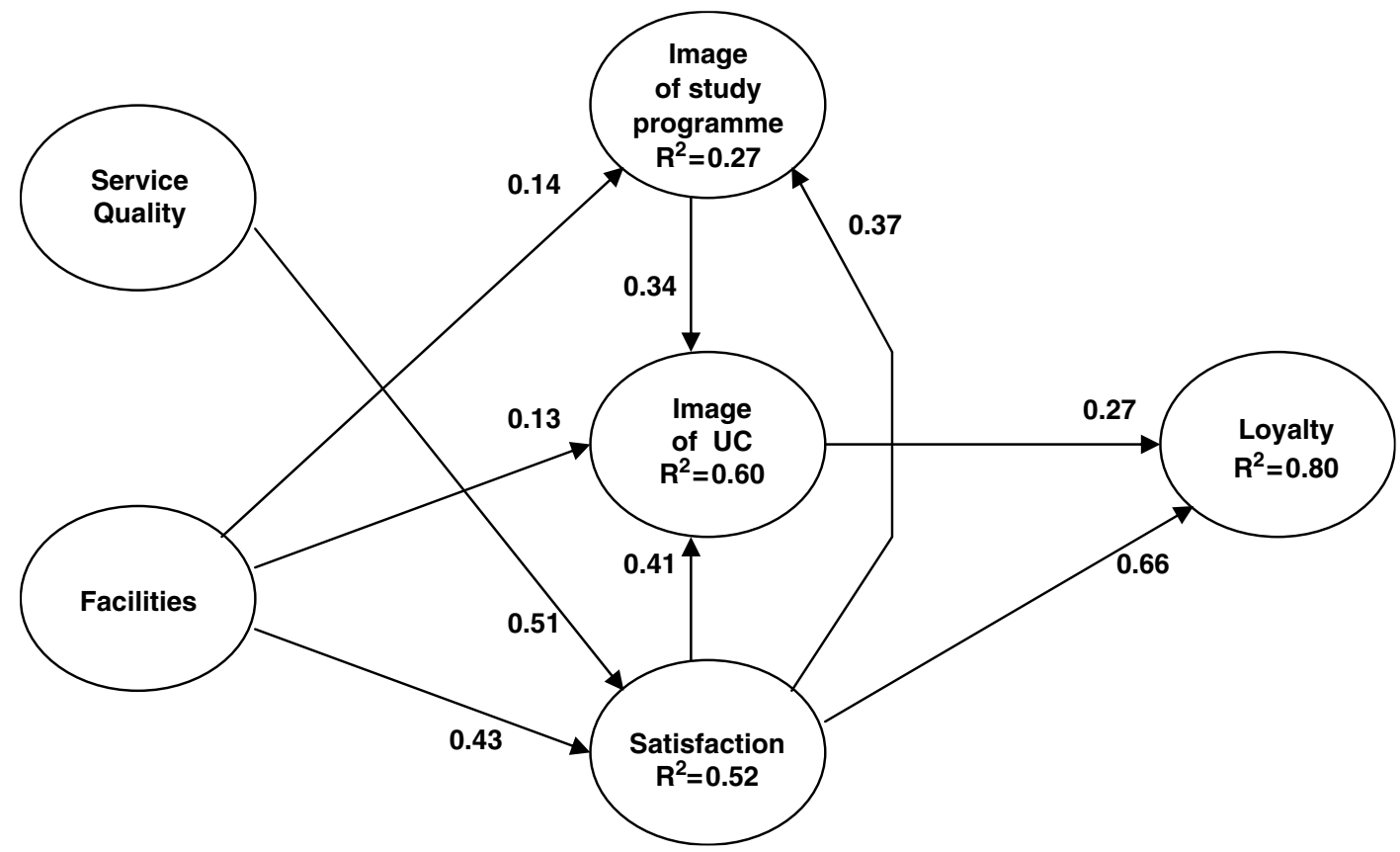

Figure 2: The preferred estimated structural model

0.70 (eg Hair et al., 2006) for both concepts (Image of University College: $\mathrm{CA}=0.83$ and $\mathrm{CR}=0.84$; Image of Study Program: $\mathrm{CA}=0.85$ and $\mathrm{CR}=0.85)$. The VE is also well above the minimum recommended value of 0.50 (Image of University College: $\mathrm{VE}=0.64$; Image 
of Study Program: $\mathrm{VE}=0.66)$. Thus, both concepts can be said to have convergent validity. The square of the correlation coefficient between the two variables has a value of 0.38 , which is far below the VEs for each of the two concepts, implying that discriminant validity may be claimed. Additionally, the associations between each of the two image variables and related variables (Student Satisfaction and Student Loyalty) are significant, and in accordance with expectations. Thus the results also appear to have nomological validity. The findings suggest that the first research question may be answered affirmatively, or that students perceive the two constructs as truly distinct.

The four main concepts of the research model (Image of Study Program, Image of University College, Student Satisfaction and Student Loyalty) are linked by six paths that are all hypothesized to be positive, cf. Hypothesis 1-Hypothesis 6 above. The findings support all hypotheses except for one: 'Student perception of the image of the study program has a positive impact on student loyalty' (Hypothesis 1). The other five hypotheses are all significant at the 0.01 level. This suggests that 'Student perception of the image of the study program has a positive impact on student perception of the image of the university college' (Hypothesis 2A); 'Student perception of the image of the university college has a positive impact on student loyalty' (Hypothesis 3); 'Student satisfaction has a positive impact on student perception of the image of the university college' (Hypothesis 4); 'Student satisfaction has a positive impact on student perception of the image of the study program (Hypothesis 5); 'Student satisfaction has a positive impact on student loyalty' (Hypothesis 6). This further suggests that the second research question may only partly be answered affirmatively. Both Student Satisfaction and Image of University College are (direct) drivers of Student Loyalty, while Image of Study Program is not. The Image of Study Program, however, is indirectly and positively related to Student Loyalty.
The direct effect from Student Satisfaction to Student Loyalty is 0.66, cf. Figure 2. Taking into consideration the indirect effects (via Image of University College and Image of Study Program), the total effect from Student Satisfaction to Student Loyalty is 0.80. Image of Study Program has an indirect effect on Student Loyalty via Image of University College of 0.09, while Image of University College has a direct effect on Student Loyalty of 0.27. This suggests that Student Satisfaction has the highest degree of association with Student Loyalty both directly and totally, that is including the indirect effects. Still, Image of University College has a significant direct effect and Image of Study Program a significant indirect effect on Student Loyalty. Additionally, it should be noted that variations of Student Satisfaction and Image of University College explain 80 per cent of the variance of Student Loyalty in the structural equation of Student Loyalty, which can be characterized as a rather high proportion.

In the reduced form equation of Student Loyalty the variance explained by the included variables (Service Quality and Facilities) represents about 44 per cent of the variance of Student Loyalty. Besides, Service Quality only loads significantly on Student Satisfaction (0.51) while Facilities loads significantly on all the three intermediary concepts of the model, that is, on Student Satisfaction (0.43), Image of University College (0.13) and Image of Study Program (0.14). Service Quality may be looked upon as representing intrinsic cues' while Facilities is representing 'extrinsic cues' (Bauer, 1960; Selnes, 1993; Andreassen and Lindestad, 1998). According to this way of thinking, the drivers of satisfaction and the drivers of images may differ, supposing that the main drivers of satisfaction are belonging to 'intrinsic attributes (cues)' and the main drivers of images are belonging to 'extrinsic attributes (cues)'.

Considering that only two factors (two groups of antecedents) are included in this research model, the proportion of variance 
explained in the reduced form equation of Student Loyalty is high. Nevertheless, the number of antecedents should be augmented in order to identify other variables important for students (Aldridge and Rowley, 1998; Elliott and Shin, 2002) and in order to indicate what should be done to obtain increased student value in a cost-effective way (McNair et al., 2001; Guilding and McManus, 2002).

\section{LIMITATIONS AND SUGGESTIONS FOR FUTURE RESEARCH}

Aalesund University College was founded in 1994 as a merger of three former educational institutions, thus being a rather new institution. Besides, it is a small institution offering about 15 undergraduate study programs. None of these programs are perceived as clearly having an 'outstanding' image. Thus, it may be enlightening to explore issues of student loyalty at an educational institution that has long-standing study programs that are widely perceived as prestigious. In this circumstance, a positive and significant path may be found between Image of Study Program and Student Loyalty.

As Student Loyalty of Aalesund University College to a large extent is driven by Student Satisfaction, the institution can be said to be satisfaction-driven. Other higher educational institutions, however, may be image-driven, which would mean that the sum of the direct and indirect path coefficients from Image of University College and from Image of Study Program to Student Loyalty would be higher than the sum of the direct and indirect path coefficients from Student Satisfaction to Student Loyalty. A comparison of satisfaction-driven and image-driven higher educational institutions can provide useful information for decision-making. Are there for instance any differences between institutions concerning prosperity? What are the differences with respect to the composition and the importance of the drivers of satisfac- tion and images? Considering that universities and other institutions of higher education have only limited resources, insight into these problem areas can help managers when making strategic decisions concerning the allocation of resources to service quality activities, image building or other activities.

Ideally studies including both Image of University College and Image of Study Program should be conducted for each study program. Unfortunately, AAUC has too few students to allow this kind of research. With respect to the homogeneousness of respondents a lot of aspects have to be considered, for example, the number of options open to students regarding subjects of a study program.

The loyalty concept is one of the variables in this study that most merits further development. As has been discussed, loyalty can be perceived as consisting of two interrelated components: one tripartite attitudinal component (cognitive, affective and conative) and another closely related behavioral component (repeat patronage). According to this approach, Student Loyalty can be measured by using various measures, such as Student Loyalty: Recommend and Student Loyalty: Patronage (Dick and Basu, 1994; Lam et al., 2004). Perhaps the two loyalty components are related differently to the other concepts. May be Student Loyalty: Recommend is closer related to images than that to satisfaction, while Student Loyalty: Patronage is closer related to satisfaction than that to images? Additionally, introducing a new approach for the measurement of student loyalty may also have a positive effect on the measurement model, particularly regarding the problems discussed with respect to Student Loyalty.

Even if the variance explained in Student Loyalty is rather high (80 per cent), other concepts such as switching costs, commitment, trust and emotions should be taken into consideration (eg Morgan and Hunt, 1994; Gounaris, 2005; Laros and Steenkamp, 2005; Johnson and Grayson, 2005). This will probably enrich the explanation of the variance 
of Student Loyalty and provide further insight. Besides, other contexts should also be studied. Should the research model be adjusted to the context, not only regarding the antecedents but also regarding the main concepts included in the model? Should the linkages between the main concepts discussed in this study be different for a image-driven institution offering higher education than is supposed here?

\section{CONCLUSIONS}

The main purpose of this paper is to look at the interplay between images and related constructs; more precisely the relationships between Student Satisfaction, Image of University College, Image of Study Program and Student Loyalty. The latter is perceived as being the ultimate dependent variable of the research model. In addition, two factors (exogenous variables) are included in the model, that is, Service Quality and Facilities.

The students perceive Image of University College and Image of Study Program as being distinct concepts. Image of Study Program is only indirectly related to Student Loyalty (via Image of University College) while Student Satisfaction and Image of University College are directly related to Student Loyalty. Taking into consideration the significance levels of the path coefficients and the variance explained of Student Loyalty, it seems reasonable to include all the four concepts in student surveys. Nevertheless, Student Satisfaction has the highest degree of association with Student Loyalty both directly and totally, representing a total effect about three times higher than the effect of Image of University College. Service Quality ('intrinsic cues') is only loading on Student Satisfaction, while Facilities ('extrinsic cues') is loading on all the three intermediary concepts (Student Satisfaction, Image of University College and Image of Study Program), implying that the drivers may differ. Managers of higher educational institutions are very interested in knowing the drivers having most to say with respect to student attraction and student retention.
Such insight can help managers when making decisions concerning the allocation of scarce resources. The context here is a small university college. Therefore, more studies are highly recommended both from higher education and from other industries.

\section{Acknowledgments}

The authors thank two anonymous reviewers for their thoughtful comments on an earlier version of this paper.

\section{Notes}

1 This summit was itself a follow-up on a summit at the Sorbonne University in Paris in May 1998 where the higher education ministers from France, Italy, the United Kingdom and Germany signed the Sorbonne Declaration on the 'harmonization of the architecture of the European Higher Education System' (http://www.dfes.gov.uk/ bologna/).

2 In 2001 the meeting was in Prague, in 2003 in Berlin, in 2005 in Bergen, Norway and in 2007 the summit will be in London (http://www. bologna-bergen2005.no/EN/BASIC/Pros-descr. HTM).

3 More information regarding ECTS (student credits) can be found at the following internet address: (http://ec.europa.eu/education/programmes/ socrates/ects/index_en.html\#2).

4 In addition to the EU-based programs, regional programs have been established, for example, Nordplus for the Nordic countries (http://siu. no/nordplus/). Besides, bilateral agreements often are established between countries, especially when one of the countries is situated outside Europe.

5 A lot of information regarding Erasmus, Sokrates and Leonardi da Vinci is available, for example, http://www.esn.org/; http://www.erasmus.ac.uk/; http://ec.europa.eu/education/programmes/socrates/ socrates_en.html; http://ec.europa.eu/education/ programmes/leonardo/leonardo_en.html

6 This abbreviation is based on the Norwegian name of the organization.

\section{References}

Abdullah, F. (2005) 'HEdPERF versus SERVPERF: The quest for ideal measuring instrument of service quality in higher education sector', Quality Assurance in Education, 13(4), 305-328. 
Aldridge, S. and Rowley, J. (1998) 'Measuring customer satisfaction in higher education', Quality Assurance in Education, 6(4), 197-204.

Anderson, E.W., Fornell, C. and Lehmann, D.R. (1994) 'Customer satisfaction, market share, and profitability: Findings from Sweden', Journal of Marketing, 58, 53-66.

Andreassen, T.W. and Lindestad, B. (1998) 'Customer loyalty and complex services: The impact of corporate image on quality, customer satisfaction and loyalty for customers with varying degrees of service expertise', International Journal of Service Industry Management, 9(1), 7-23.

Arnaboldi, M. and Azzone, G. (2005) 'Incrementalism and strategic change: A university's experience', International Journal of Educational Management, 19(7), 552-563.

Athanassopoulos, A.D. (2000) 'Customer satisfaction cues to support market segmentation and explain switching behavior', Journal of Business Research, 47, 191-207.

Athiyaman, A. (1997) 'Linking student satisfaction and service quality perceptions: The case of university education', European Journal of Marketing, 31(7), 528-540.

Bauer, R.A. (1960) 'Consumer behavior as risk taking', in R.S. Hancock (ed.), Dynamic Marketing for a Changing World, Proceedings of the 43rd Conference of the American Marketing Association, American Marketing Association, Chicago IL, pp. 389-398.

Brown, T.J., Dacin, P.A., Pratt, M.G. and Whetten, D.A. (2006) 'Identity, intended image, construed image, and reputation: An interdisciplinary framework and suggested terminology', Journal of the Academy of Marketing Science, 34(2), 99-106.

Browne, B.A., Kaldenberg, D.O., Browne, W.G. and Brown, D.J. (1998) 'Student as customer: Factors affecting satisfaction and assessments of institutional quality', Journal of Marketing for Higher Education, 8(3), $1-14$.

Bush, V., Ferrell, O.C. and Thomas Jr., J.L. (1998) 'Marketing the business school: An exploratory investigation', Journal of Marketing Education, 20(1), $16-23$

Byrne, B.M. (1998) Structural Equation Modeling with LISREL, PRELIS, and SIMPLIS. Basic Concepts, Applications, and Programming, Lawrence Erlbaum Associates Publishers, Mahwah, NJ, USA.

Chan, L.K., Hui, Y.V., Lo, H.P., Tse, S.K., Tso, G.K.F. and Wu, M.L. (2003) 'Consumer satisfaction index: new practice and findings', European Journal of Marketing, 37(5/6), 872-909.

Chun, R. (2005) 'Corporate reputation: Meaning and measurement', International Journal of Management Reviews, 7(2), 91-109.
Cronin, J.J. and Taylor, S.S. (1992) 'Measuring service quality: Reexamination and extension', Journal of Marketing, 56, 55-68.

Davies, G., Chun, R., da Silva, R.V. and Roper, S. (2004) 'A corporate character scale to assess employee and customer views of organizational reputation', Corporate Reputation Review, 7(2), 125-146.

DeShields Jr., O.W., Kara, A. and Kaynak, E. (2005) 'Determinants of business student satisfaction and retention in higher education: Applying Herzberg's two-factor theory', International Journal of Educational Management, 19(2), 128-139.

Dick, A. and Basu, K. (1994) 'Customer loyalty: Towards an integrated framework', Journal of the Academy of Marketing Science, 22, 99-113.

Dowling, G.R. (1986) 'Managing your corporate images', Industrial Marketing Management, 15, 109-115.

Dowling, G.R. (1988) 'Measuring corporate images: A review of alternative approaches', Journal of Business Research, 17(1), 27-34.

Dowling, G.R. (2001) Creating Corporate Reputations, Oxford University Press, NY, USA.

Drucker, P.F. (1954) The Practice of Management, Harper and Row, NY, USA.

Elliott, K.M. and Healy, M.A. (2001) 'Key factors influencing student satisfaction related to recruitment and retention', Journal of Marketing for Higher Education, 10(4), 1-11.

Elliott, K.M. and Shin, D. (2002) 'Student Satisfaction: An alternative approach to assessing this important concept', Journal of Higher Education Policy and Management, 24(2), 197-209.

Felton,A.P. (1959) 'Making the marketing concept work', Harvard Business Review, 37(July/Aug.), 55-65.

Fombrun, C. (1996) Reputation: Realizing Value from the Corporate Image, Harvard Business School Press, Boston, USA.

Fombrun, C. and Shanley, M. (1990) 'What's in a name? Reputation building and corporate strategy', Academy of Management Journal, 33(2), 233-258.

Fombrun, C. and van Riel, C.B.M. (1997) 'The reputational landscape', Corporate Reputation Review, 1 (1 and 2), 5-13.

Fombrun, C. and van Riel, C.B.M. (2003) Fame \& Fortune: How Successful Companies Build Winning Reputations, Prentice Hall, Upper Saddle River, NJ, USA.

Fornell, C. (1992) 'A national customer satisfaction barometer: The Swedish experience', Journal of Marketing, 56, 6-21.

Fornell, C., Johnson, M.D., Anderson, E.W., Cha, J. and Bryant, B.E. (1996) 'The American customer 
Kaplan, R.S. and Norton, D.P. (1996) Translating Strategy into Action: The Balanced Scorecard, Harvard Business School Press, Boston, MA, USA.

satisfaction index: Nature, purpose, and findings', Journal of Marketing, 60, 7-18.

Giese, J.L. and Cote, J.A. (2000) 'Defining customer satisfaction', Academy of Marketing Science Review, 01, $1-34$.

Gounaris, S. (2005) 'Trust and commitment influences on customer retention: insights from businessto-business services', Journal of Business Research, 58, 126-140.

Grönroos, C. (1989) 'Defining marketing: A marketoriented approach', European Journal of Marketing, 23(1), 52-60.

Guilding, C. and McManus, L. (2002) 'The incidence, perceived merit and antecedents of customer accounting: An exploratory note', Accounting, Organizations and Society, 27, 45-59.

Hair Jr., J.F., Black, W.C., Babin, B.J., Anderson, R.E. and Tatham, R.L. (2006) Multivariate Data Analysis, 6th edn, Prentice-Hall, Upper Saddle River, NJ, USA.

Heaphy, M.S. and Gruska, G.F. (1995) The Malcolm Baldridge National Quality Award: A Yardstick for Quality Growth, Addison Wesley, Reading, MA, USA.

Helgesen, Ø. (2006) 'Are loyal customers profitable? Customer satisfaction, customer (action) loyalty and customer profitability at the individual level', Journal of Marketing Management, 22, 245-266.

Helm, S. (2005) 'Designing a formative measure for corporate reputation', Corporate Reputation Review, 8(2), 95-109.

Henning-Thurau, T., Lager, M.F. and Hansen, U. (2001) 'Modelling and managing student loyalty: An approach based on the concept of relationship quality', Journal of Service Research, 3(1), 331-344.

Johnson, D. and Grayson, K. (2005) 'Cognitive and affective trust in service relationships', Journal of Business Research, 58, 500-507.

Johnson, M.D. and Gustafsson, A. (2000) Improving Customer Satisfaction, Loyalty, and Profit: An Integrated Measurement and Management System, Jossey-Bass, San Francisco, CA, USA.

Johnson, M.D., Gustafsson, A., Andreassen, T.W., Lervik, L. and Cha, J. (2001) 'The evolution and future of national customer satisfaction index models', Journal of Economic Psychology, 22, 217-245.

Jones, M.A., Mothersbaugh, D.L. and Beatty, S.E. (2000) 'Switching barriers and repurchase inten-tions in services', Journal of Retailing, 76(2), 259-274.

Jöreskog, K.G. and Sörbom, D. (1996) LISREL 8 User's Reference Guide, Scientific Software International, Chicago, USA.

Jöreskog, K.G., Sörbom, D., Du Toit, S. and Du Toit, M. (2001) LISREL 8: New Statistical Features, Scientific Software International, Chicago, USA.
Kaplan, R.S. and Norton, D.P. (2001) The StrategyFocused Organization: How Balanced Scorecard Companies Thrive in the New Business Environment, Harvard Business School Press, Boston, MA, USA.

Kaplan, R.S. and Norton, D.P. (2004) Strategy Maps: Converting Intangible Assets into Tangible Outcomes, Harvard Business School Press, Boston, MA, USA.

Kinnear, T.C., Bernhardt, K.L. and Krentler, K.A. (1995) Principles of Marketing, 4th edn, HarperCollins, NY, USA.

Kotler, P., Armstrong, G., Saunders, J. and Wong, V. (2002) Principles of Marketing, 3rd European Edition, Pearson Education Ltd, Essex, England.

Kotler, P. and Fox, K.F.A. (1995) Strategic Marketing for Educational Institutions, Prentice-Hall, Englewood Cliffs, NJ, USA.

Lam, S.Y., Shankar, V., Erramilli, M.K. and Murthy, B. (2004) 'Customer value, satisfaction, loyalty, and switching costs: An illustration from a business-tobusiness service context', Journal of the Academy of Marketing Science, 32(3), 293-311.

Laros, F.J.M. and Steenkamp, J.-B.E.M. (2005) 'Emotions in consumer behavior: A hierarchical approach', Journal of Business Research, 58, 1437-1445.

Lemmink, J., Schuijf, A. and Streukens, S. (2003) 'The role of corporate image and company employment image in explaining application intentions', Journal of Economic Psychology, 24, 1-15.

MacMillan, K., Money, K., Downing, S. and Hillenbrand, C. (2005) 'Reputation in relationships: Measuring experiences, emotions and behaviors', Corporate Reputation Review, 8(2), 214-232.

Mägi, A. (1999) Store Loyalty? - An Empirical Study of Grocery Shopping, Stockholm School of Economics (EFI), Stockholm, Sweden.

Markwick, N. and Fill, C. (1997) 'Towards a framework for managing corporate identity', European Journal of Marketing, 31(5/6), 396-409.

Marzo-Navarro, M., Pedraja-Iglesias, M. and RiveraTorres, P. (2005a) 'A new management element for universities: Satisfaction with the offered courses', International Journal of Educational Management, 19(6), 505-526.

Marzo-Navarro, M., Pedraja-Iglesias, M. and RiveraTorres, P. (2005b) 'Measuring customer satisfaction in summer courses', Quality Assurance in Education, 13(1), 53-65.

McNair, C.J., Polutnik, L. and Silvi, R. (2001) 'Cost management and value creation: The missing link', The European Accounting Review, 10(1), 33-50. 
Morgan, R.M. and Hunt, S.D. (1994) 'The commitment-trust theory of relationship marketing', Journal of Marketing, 58(July), 20-38.

Oakland,J.S. (1995) Total Quality Management:Text with Cases, Butterworth-Heinemann Ltd, Oxford.

Olins, W. (1999) The New Guide to Corporate Identity, Gower/The Design Council.

Oliver, R.L. (1980) 'A cognitive model of the antecedents and consequences of satisfaction decisions', Journal of Marketing Research, 17, 460-469.

Oliver, R.L. (1997) Satisfaction: A Behavioral Perspective On The Consumer, McGraw-Hill, New York.

Oliver, R.L. (1999) 'Whence consumer loyalty?' Journal of Marketing, 63(Special Issue 1999), 33-44.

Parasuraman, A., Zeithaml, V.A. and Berry, L.L. (1988) 'SERVQUAL: A multi-item scale for measuring consumer perceptions of service quality', Journal of Retailing, 64(1), 12-40.

Parasuraman, A., Zeithaml,V.A. and Berry, L.L. (1994) 'Alternative scales for measuring service quality: A comparative assessment based on psychonometric and diagnostic criteria', Journal of Retailing, 70(3), 201-230.

Passow, T., Fehlmann, R. and Grahlow, H. (2005) 'Country reputation - from measurement to management: The case of Liechtenstein', Corporate Reputation Review, 7(4), 309-326.

Reichheld, F.F. (1996) The Loyalty Effect: The Hidden Force Behind Growth, Profits, and Lasting Value, Harvard Business School Press, Boston, MA, USA.

Reynolds, F.D., Darden, W.R. and Martin, W.S. (1974/75) 'Developing an image of the storeloyal customer', Journal of Retailing, 4(Winter), 73-84.

Rindova, V.P. and Fombrun, C.J. (1999) 'Constructing competitive advantage: The role of firm-constituent interactions', Strategic Management Journal, 20, 691-710.

Rodie, A.R. and Kleine, S.S. (2000) 'Customer participation in services production and delivery', in T.A. Swartz and D. Iacobucci (eds.), Handbook of Service Marketing and Management, Sage, Thousand Oaks, CA, pp. 111-125.

Ryan, M.J., Buzas, T. and Ramaswamy, V. (1995) 'Making CSM a power tool: Composite indices boost the value of satisfaction measures for decision making', Marketing Research, Summer, 7(3), $11-16$.

Schertzer, C.B. and Schertzer, S.M.B. (2004) 'Student satisfaction and retention: A conceptual model', Journal of Marketing for Higher Education, 14(1), 79-91.
Schuler, M. (2004) 'Management of the organizational image: A method for organizational image configuration', Corporate Reputation Review, 7(1), 37-53.

Selame, E. and Selame, J. (1988) The Company Image Building your Identity and Influence in the Marketplace, John Wiley and Sons, New York.

Selnes, F. (1993) 'An examination of the effects of product performance on brand reputation, satisfaction and loyalty', European Journal of Marketing, 27(9), 19-35.

Seth, N., Deshmukh, S.G. and Vrat, P. (2004) 'Service quality models: A review', International Journal of Quality \& Reliability Management, 22(9), 913-949.

Sevier, R. (1994) 'Image is everything', College and University, Winter, 60-75.

Solomon, M.R. (1994) Consumer Behavior, 2nd edn., Allyn and Bacon, Needham Heights, MA, USA.

Standifird, S.S. (2005) 'Reputation among peer academic institutions: An investigation of the US News and World Report's rankings', Corporate Reputation Review, 8(3), 233-244.

Theus, K.T. (1993) 'Academic reputations: The process of formation and decay', Public Relations Review, 19(Fall), 277-291.

Williams, R.J., Schnake, M.E. and Fredenberger, W. (2005) 'The impact of corporate strategy on a firm's reputation', Corporate Reputation Review, 8(3), 187-197.

Wilson, A. (2003) Marketing Research: An Integrated Approach, Pearson Education Ltd, Essex, England.

Yeung, M.C.H. and Ennew, C.T. (2000) 'From customer satisfaction to profitability', Journal of Strategic Marketing, 8(4), 313-326.

Yoon, E., Guffey, H.J. and Kijewski, V. (1993) 'The effects of information and company reputation on intentions to buy a business service', Journal of Business Research, 27, 215-228.

Zabala, I., Panadero, G., Gallardo, L.M., Amate, C.M., Sánchez-Galindo, M., Tena, I. and Villalba, I. (2005) 'Corporate reputation in professional services firms: Reputation management based on intellectual capital management', Corporate Reputation Review, 8(1), 59-71.

Zeithaml,V.A. (2000) 'Service quality, profitability, and the economic worth of customers: What we know and what we need to learn', Journal of the Academy of Marketing Science, 28(1), 67-85.

Zeithaml,V.A., Berry, L.L. and Parasuraman, A. (1996) 'The behavioral consequences of service quality', Journal of Marketing, 60(April), 31-46. 


\section{Appendix A}

Presents the statistical metrics of the 25 items (see Table 1A).

Table 1A: Statistical Metrics of the 25 Items (Indicators) $(n=454)$

\begin{tabular}{|c|c|c|c|c|c|}
\hline Variables (items/factors/concepts) & Symbol & Mean & S.D. & Skewness & Kurtosis \\
\hline Satisfaction with the reading room & $\mathrm{X}_{1}$ & 3.57 & 1.79 & 0.09 & -1.05 \\
\hline Satisfaction with the library & $\mathrm{X}_{2}$ & 4.74 & 1.26 & -0.43 & 0.22 \\
\hline Satisfaction with the locations of lectures & $\mathrm{X}_{3}$ & 4.57 & 1.31 & -0.18 & -0.37 \\
\hline Satisfaction with the group rooms & $\mathrm{X}_{4}$ & 3.37 & 1.65 & 0.23 & -0.84 \\
\hline Satisfaction with the cleaning & $\mathrm{X}_{5}$ & 5.29 & 1.27 & -0.66 & 0.16 \\
\hline Satisfaction with the temperature indoor & $\mathrm{X}_{6}$ & 3.43 & 1.75 & 0.34 & -0.93 \\
\hline Satisfaction with the canteen & $\mathrm{X}_{7}$ & 4.80 & 1.50 & -0.54 & -0.47 \\
\hline Facilities $\left(\mathrm{X}_{1}-\mathrm{X}_{7}\right)$ & $\xi_{1}$ & & & & \\
\hline Satisfaction with the pedagogical quality of lectures & $\mathrm{X}_{8}$ & 3.81 & 1.09 & -0.22 & -0.04 \\
\hline Satisfaction with the feedback from lecturers & $\mathrm{X}_{9}$ & 3.59 & 1.29 & -0.04 & -0.35 \\
\hline Satisfaction with the professional quality of lectures & $\mathrm{X}_{10}$ & 4.46 & 1.10 & -0.31 & 0.02 \\
\hline $\begin{array}{l}\text { Satisfaction with the students' mid-term evaluations } \\
\text { regarding their study }\end{array}$ & $\mathrm{X}_{11}$ & 3.70 & 1.23 & -0.14 & -0.08 \\
\hline Satisfaction with the quality of study materials & $\mathrm{X}_{12}$ & 4.50 & 1.08 & -0.29 & 0.27 \\
\hline Service Quality of studies $\left(\mathrm{X}_{8}-\mathrm{X}_{12}\right)$ & $\xi_{2}$ & & & & \\
\hline $\begin{array}{l}\text { Satisfaction with the university college (spontaneous } \\
\text { judgement) }\end{array}$ & $\mathrm{Y}_{1}$ & 4.25 & 1.10 & -0.41 & 0.21 \\
\hline Satisfaction with the university college in general & $\mathrm{Y}_{2}$ & 4.17 & 1.07 & -0.44 & 0.17 \\
\hline $\begin{array}{l}\text { Satisfaction with the university college compared with } \\
\text { expectations }\end{array}$ & $\mathrm{Y}_{3}$ & 3.95 & 1.29 & -0.20 & -0.38 \\
\hline $\begin{array}{l}\text { Satisfaction with the university college compared with an } \\
\text { ideal one }\end{array}$ & $\mathrm{Y}_{4}$ & 3.50 & 1.26 & -0.05 & -0.49 \\
\hline Student satisfaction $\left(\mathrm{Y}_{1}-\mathrm{Y}_{4}\right)$ & $\eta_{1}$ & & & & \\
\hline $\begin{array}{l}\text { Perception of the university college among the general } \\
\text { public }\end{array}$ & $\mathrm{Y}_{6}$ & 4.17 & 1.14 & -0.13 & 0.31 \\
\hline Perception of the university college among employers & $\mathrm{Y}_{7}$ & 4.41 & 1.13 & -0.28 & 0.50 \\
\hline Image of the university college $\left(\mathrm{Y}_{5}-\mathrm{Y}_{7}\right)$ & $\eta_{2}$ & & & & \\
\hline Perception of the study among your circle of acquaintances & $\mathrm{Y}_{8}$ & 4.29 & 1.33 & -0.33 & 0.07 \\
\hline Perception of the study among the general public & $\mathrm{Y}_{9}$ & 4.53 & 1.21 & -0.11 & 0.15 \\
\hline Perception of the study among employers & $\mathrm{Y}_{10}$ & 4.75 & 1.22 & -0.19 & -0.12 \\
\hline Image of the study programme $\left(\mathrm{Y}_{8}-\mathrm{Y}_{10}\right)$ & $\eta_{3}$ & & & & \\
\hline $\begin{array}{l}\text { Probability of recommending the university college to } \\
\text { friends/acquaintances }\end{array}$ & $\mathrm{Y}_{11}$ & 4.13 & 1.57 & -0.19 & -0.67 \\
\hline $\begin{array}{l}\text { Probability of attending the same university college if } \\
\text { starting anew }\end{array}$ & $\mathrm{Y}_{12}$ & 4.10 & 1.90 & -0.16 & -1.05 \\
\hline $\begin{array}{l}\text { Probability of attending new courses/further education } \\
\text { at the university college }\end{array}$ & $\mathrm{Y}_{13}$ & 4.14 & 1.81 & -0.18 & -0.95 \\
\hline Student loyalty: 2 items $\left(\mathrm{Y}_{11}\right.$ and $\left.\mathrm{Y}_{12}\right)$ & $\eta_{4}$ & & & & \\
\hline
\end{tabular}




\section{Appendix B}

Presents the correlation matrix (see Tables $2 \mathrm{~A}$ and $2 \mathrm{~B}$ ).

Table 2A: Correlation Matrix of the 25 Items (Indicators) - Part $1(n=454)$

\begin{tabular}{|c|c|c|c|c|c|c|c|c|c|c|c|c|}
\hline & $X 1$ & $X 2$ & X3 & $X 4$ & $X 5$ & $X 6$ & $X 7$ & X8 & X9 & X10 & X11 & $X 12$ \\
\hline $\mathrm{X}_{1}$ & 1.00 & & & & & & & & & & & \\
\hline $\mathrm{X}_{2}$ & 0.52 & 1.00 & & & & & & & & & & \\
\hline$X_{3}$ & 0.34 & 0.45 & 1.00 & & & & & & & & & \\
\hline $\mathrm{X}_{4}$ & 0.40 & 0.32 & 0.37 & 1.00 & & & & & & & & \\
\hline $\mathrm{X}_{5}$ & 0.37 & 0.43 & 0.33 & 0.29 & 1.00 & & & & & & & \\
\hline $\mathrm{X}_{6}$ & 0.37 & 0.26 & 0.33 & 0.33 & 0.28 & 1.00 & & & & & & \\
\hline $\mathrm{X}_{7}$ & 0.37 & 0.33 & 0.24 & 0.33 & 0.26 & 0.20 & 1.00 & & & & & \\
\hline $\mathrm{X}_{8}$ & 0.08 & 0.16 & 0.02 & 0.05 & 0.07 & -0.06 & -0.02 & 1.00 & & & & \\
\hline $\mathrm{X}_{9}$ & 0.04 & 0.13 & 0.01 & -0.02 & 0.09 & -0.04 & 0.03 & 0.45 & 1.00 & & & \\
\hline $\mathrm{X}_{10}$ & 0.18 & 0.23 & 0.10 & 0.05 & 0.12 & 0.06 & 0.09 & 0.56 & 0.35 & 1.00 & & \\
\hline $\mathrm{X}_{11}$ & 0.04 & 0.08 & -0.08 & 0.01 & 0.02 & -0.11 & 0.05 & 0.36 & 0.40 & 0.21 & 1.00 & \\
\hline$X_{12}$ & 0.08 & 0.17 & 0.13 & 0.06 & 0.17 & 0.05 & 0.13 & 0.29 & 0.24 & 0.28 & 0.25 & 1.00 \\
\hline$Y_{1}$ & 0.29 & 0.33 & 0.32 & 0.26 & 0.19 & 0.18 & 0.29 & 0.30 & 0.27 & 0.39 & 0.21 & 0.23 \\
\hline $\mathrm{Y}_{2}$ & 0.34 & 0.39 & 0.33 & 0.30 & 0.26 & 0.25 & 0.29 & 0.35 & 0.31 & 0.42 & 0.22 & 0.24 \\
\hline $\mathrm{Y}_{3}$ & 0.24 & 0.30 & 0.25 & 0.21 & 0.23 & 0.16 & 0.27 & 0.32 & 0.28 & 0.41 & 0.24 & 0.15 \\
\hline$Y_{4}$ & 0.24 & 0.30 & 0.17 & 0.16 & 0.20 & 0.10 & 0.23 & 0.39 & 0.34 & 0.39 & 0.36 & 0.28 \\
\hline$Y_{5}$ & 0.27 & 0.30 & 0.28 & 0.23 & 0.17 & 0.18 & 0.22 & 0.23 & 0.21 & 0.30 & 0.21 & 0.13 \\
\hline$Y_{6}$ & 0.30 & 0.31 & 0.23 & 0.19 & 0.19 & 0.21 & 0.19 & 0.23 & 0.27 & 0.33 & 0.18 & 0.15 \\
\hline $\mathrm{Y}_{7}$ & 0.31 & 0.25 & 0.18 & 0.13 & 0.21 & 0.20 & 0.21 & 0.25 & 0.26 & 0.36 & 0.17 & 0.18 \\
\hline $\mathrm{Y}_{8}$ & 0.19 & 0.17 & 0.21 & 0.18 & 0.11 & 0.14 & 0.19 & 0.22 & 0.25 & 0.32 & 0.20 & 0.18 \\
\hline $\mathrm{Y}_{9}$ & 0.17 & 0.21 & 0.19 & 0.12 & 0.14 & 0.21 & 0.19 & 0.12 & 0.18 & 0.22 & 0.12 & 0.15 \\
\hline$Y_{10}$ & 0.21 & 0.22 & 0.22 & 0.13 & 0.17 & 0.25 & 0.13 & 0.10 & 0.11 & 0.17 & 0.07 & 0.16 \\
\hline$Y_{11}$ & 0.29 & 0.32 & 0.24 & 0.23 & 0.25 & 0.19 & 0.25 & 0.29 & 0.28 & 0.42 & 0.30 & 0.23 \\
\hline$Y_{12}$ & 0.23 & 0.25 & 0.17 & 0.14 & 0.20 & 0.11 & 0.18 & 0.26 & 0.23 & 0.35 & 0.23 & 0.18 \\
\hline $\mathrm{Y}_{13}$ & 0.14 & 0.17 & 0.07 & -0.01 & 0.15 & 0.01 & 0.08 & 0.20 & 0.26 & 0.26 & 0.24 & 0.20 \\
\hline
\end{tabular}

Table 2B: Correlation Matrix of the 25 Items (Indicators) - Part $2(n=454)$

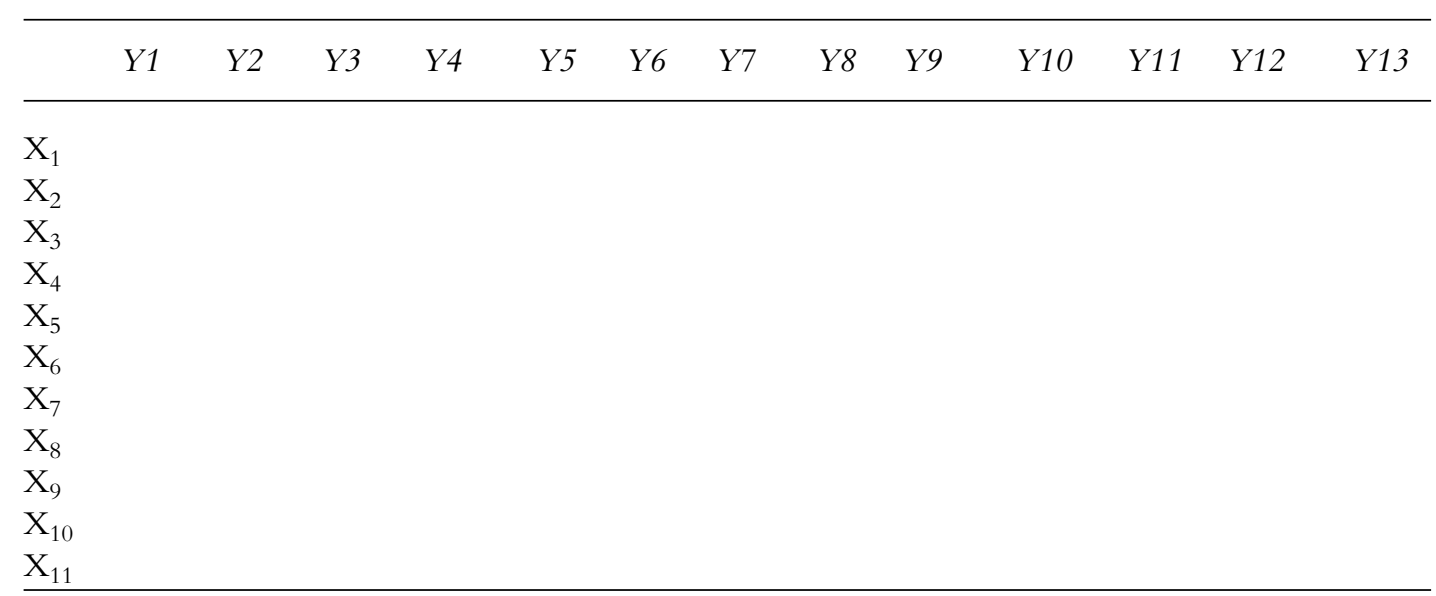


Table 2B: Continued

\begin{tabular}{|c|c|c|c|c|c|c|c|c|c|c|c|c|c|}
\hline & $Y 1$ & $Y 2$ & $Y 3$ & $Y 4$ & $Y 5$ & $Y 6$ & $Y 7$ & $Y 8$ & $Y 9$ & Y10 & $Y 11$ & $Y 12$ & $Y 13$ \\
\hline \multicolumn{14}{|l|}{$\mathrm{X}_{12}$} \\
\hline $\mathrm{Y}_{1}$ & 1.00 & & & & & & & & & & & & \\
\hline $\mathrm{Y}_{2}$ & 0.85 & 1.00 & & & & & & & & & & & \\
\hline$Y_{3}$ & 0.68 & 0.70 & 1.00 & & & & & & & & & & \\
\hline $\mathrm{Y}_{4}$ & 0.64 & 0.67 & 0.69 & 1.00 & & & & & & & & & \\
\hline$Y_{5}$ & 0.51 & 0.55 & 0.50 & 0.50 & 1.00 & & & & & & & & \\
\hline$Y_{6}$ & 0.49 & 0.53 & 0.49 & 0.49 & 0.71 & 1.00 & & & & & & & \\
\hline$Y_{7}$ & 0.41 & 0.41 & 0.36 & 0.39 & 0.55 & 0.62 & 1.00 & & & & & & \\
\hline$Y_{8}$ & 0.46 & 0.44 & 0.43 & 0.36 & 0.46 & 0.47 & 0.45 & 1.00 & & & & & \\
\hline $\mathrm{Y}_{9}$ & 0.32 & 0.34 & 0.35 & 0.26 & 0.37 & 0.41 & 0.35 & 0.74 & 1.00 & & & & \\
\hline$Y_{10}$ & 0.29 & 0.31 & 0.28 & 0.22 & 0.36 & 0.41 & 0.51 & 0.56 & 0.64 & 1.00 & & & \\
\hline$Y_{11}$ & 0.67 & 0.71 & 0.72 & 0.72 & 0.61 & 0.59 & 0.51 & 0.50 & 0.37 & 0.37 & 1.00 & & \\
\hline$Y_{12}$ & 0.54 & 0.56 & 0.59 & 0.61 & 0.46 & 0.46 & 0.46 & 0.39 & 0.31 & 0.33 & 0.70 & 1.00 & \\
\hline$Y_{13}$ & 0.35 & 0.40 & 0.38 & 0.42 & 0.42 & 0.34 & 0.33 & 0.27 & 0.21 & 0.21 & 0.50 & 0.62 & 1.00 \\
\hline
\end{tabular}

